\title{
NEW UKARINIAN SCHOOL EDUCATIONAL REFORMS AND PROFFESSIONAL MASTERSHIP OF THE PHYSICAL EDUCATION TEACHER
}

\author{
Nataliya Sorokolit \\ Lviv State University of Physical Culture named after Ivan Boberskyj, Ukraine \\ Mykola Lukjanchenko \\ Drohobych Ivan Franko State Pedagogical University, Ukraine \\ Iryna Turchyk \\ Drohobych Ivan Franko State Pedagogical University, Ukraine \\ Roman Chopyk \\ Drohobych Ivan Franko State Pedagogical University, Ukraine
}

\begin{abstract}
The physical education teachers' attitude towards reforming of education in Ukraine in terms of reform "New Ukrainian School" was analyzed in the article. The physical education specialists' thoughts according these reforms' impact on forming of professional mastership of teachers were analyzed in the article. The goal of the research is to provide comparable analysis of the support level of New Ukrainian School reforms that have impact on building professional improvement of physical education teachers.

In order to reach the goal such methods were applied as analysis and generalization of literature sources, teachers' survey, based on questionnaire, its mathematic processing and comparative analysis. There were questioned 341 teachers from 7 Ukrainian regions with different qualification levels and pedagogical experience. All the respondents have given their permission in participation in the research.

The different levels of support of educational reforms among physical education teachers were found out. Innovations, in general, have higher than average and lower than average levels of support. The highest level of support has such innovation as freedom to choose or create educational program - 77,4\%. However, even with high level of support, 41,9\% of teachers think that they should teach pupils according to the only studying program, that is submitted by profile ministry. Only 6,5\% of respondents are ready to create their own studying programs. However, 33,8\% of teachers think the studying program should be adapted according to conditions of educational establishments. In order to build professional mastership, it is essential to imply different forms of qualification improvements $(71,3 \%)$, distance studying during course retraining (59,7\%), teachers' certification (53,6\%). The lowest level of support has decentralization in management of educational establishment $(39,1 \%)$.
\end{abstract}


Sorokolit et al., 2021. New Ukarinian School Educational Reforms and Proffessional Mastership of the Physical Education Teacher

Keywords: educational changes, physical education, professional mastership reform, teachers.

\section{Introduction}

The modernization of the general secondary school system motivates pedagogical worker to realize the ideas of teachers-innovators. This works as a basis for creating its own pedagogical mastership (Vindjuk, 2013). Such situation requires independent preparation of the specialist, who is aware about his or her social responsibility, who is the subject of individual and professional development, who can achieve pedagogical goals: to set a goal, to determine the strategy and specific methodic to build professional activity (Fedorchuk, E., Konkova, Fedorchuk, V., \& Zaremba, 2006). The modern stage of development of the domestic education is characterized by implementing of educational reform "New Ukrainian School", having a goal to improve educational quality significantly. The educational innovations, declared by the reform, intersect nor only with pupils, but with teachers as well.

Moiseiev (2018) claims in his researches that specifics of the New Ukrainian concept is increasing requirements towards teachers' professional mastership in general and physical education teachers in particular.

The researches by domestic scientists Fedorchuk, E., Konkova, Fedorchuk, V., \& Zaremba, 2006; Matviichuk, 2015a; Moiseiev, 2017; Penkovets, 2013; Radkevych, 2012; Savchenko, 2011; Sorokolit, Shyyan, Lukjanchenko, \& Turchyk, 2017; Veselovskyi, Redchyts, Ilchyshyn, 2016; Yurieva, Sava, \& Yavorskyi, 2009 affirm significant interest towards forming pedagogical mastership of physical education teachers. Thus, Yurieva, Sava and Yavorskyi (2009) claim that physical education specailists' professional forming in practical activity with pupils is influenced by self-education and selfdiscipline directly. Savchenko (2011) substantiates ways to build professional mastership in the system of postgraduate pedagogical education among physical education teachers working in elementary school. Penkovets (2013) has reviewed theoretical aspects of stages of building mastership among future physical education teachers in present conditions. Matviichuk (2015 a) has discovered specifics of forming professional mastership among physical education teachers. Veselovskyi et all. (2016) has determined problems, directions of specialists' professional forming towards practical activity and professional self-development. Kurnyshev (2017) has put attention on discovering pedagogical conditions for professional self-development of future physical education teachers. Moiseiev (2017) has determined modern trends in the semantic environment of the construct "pedagogical mastership". 
The question of forming of pedagogical mastership among physical education teachers is relevant in researches of foreign scientists, such as Avalos, 2011; Dezimone, 2009; Konukman, 2015; Kougioumtzis, Patriksson, \& Strahlman, 2011; Little, 1993; Tannehill, Demirhan, Chaplova, \& Avsar, 2021.

The pedagogical mastership of the physical education teacher was the object of research of Ukrainian researches in lots of dissertation works: Arefieva, 2010; Azhyppo, 2013; Deminska, 2014; Kurnyshev, 2017; Matviichuk, 2015b; Omelchuk, 2014; Papucha, 2010; Stepanchenko, 2017. The various problems of creating professional development of physical education teacher are discovered in these works. The relevance of our research is proved by adoption of New Order for professional development of pedagogical and scientific-pedagogical workers. Thus, there has arose demand to investigate physical education teachers' opinion according the effectiveness of educational changes and its influence of pedagogical mastership.

The goal of the research is to perform comparative analysis of support towards educational reforms from New Ukrainian School that influence forming of professional development of physical education teachers.

\section{Methodology}

The participants of the research are physical education teachers from 7 Ukrainian regions, in particular Lviv region $(\mathrm{n}=50-25,8 \%)$; Ivano-Frankivsk region $(\mathrm{n}=53-13,6 \%)$; Ternopil region $(\mathrm{n}=54-13,8 \%)$; Khmelnitsky region $(\mathrm{n}=48-12,3 \%)$; Vinnytsia region $(\mathrm{n}=50-12,8 \%)$; Dnipropetrovsk region $(n=36-9,2 \%)$ and Kherson region $(n=50-12,8 \%)$. In total, 341 physical education teachers participated in the survey, among them are 227 of man $(66,6 \%)$ and 114 of women $(33,4 \%)$. It worth to mention that teachers are with different pedagogical experience and qualification level. Thus, there were 153 teachers $(44,9 \%)$ with higher qualification category, 88 teachers $(25,8 \%)$ with first category, 55 teachers $(16,1 \%)$ with second category and 45 teachers $(13,2 \%)$ with a "specialist" category.

Such methods were applied in the research as analysis and generalization of literature sources (it allowed us to determine relevance of our research and to form the goal); physical education teachers' survey (by questionnaire - with a goal to find out physical education teachers' attitude towards influence of educational reforms from New Ukrainian School on building professional mastership; it was anonymous). The questionnaire was consisted from 26 questions. We have succeeded in determination of various levels of support of 
Sorokolit et al., 2021. New Ukarinian School Educational Reforms and Proffessional Mastership of the Physical Education Teacher

educational reforms that are nowadays implementing in general secondary educational establishments.

The survey was performed on the basis of regional postgraduate establishments of pedagogical education during courses of qualification improvement during the period from September'19 till February'20. All the respondents gave their approval in participation in the survey (Sorokolit, 2018).

The materials from research were elaborated in the program Microsoft Office Excel. We have determined arithmetic mean value of educational reforms support in percentage by representatives of all regions and support level in particular regions in percent. What is more, we have applied the Pearson's criteria $\chi^{2}$ to reveal probability of respondents' opinion disagreement from regions. With $\mathrm{p}<0,05$ the difference in respondents' answers is statistically significant.

It was managed to perform comparative analysis of support level of educational reforms by generalization of survey results. With data interpretation we applied scale of reforms' support that consists of 4 levels: low, lower than average, higher than average and high. The low level of support forecasts the support of $0-25 \%$ of respondents; lower than average $-26-50 \%$ of respondents; higher than average $-51-76 \%$ of respondents; high level $-76-100 \%$ of physical education teachers (Sorokolit, Rymar, \& Bodnarchuk, 2020).

\section{The Results}

The results of the survey of physical education teachers give us opportunity to state that specialist in physical education are actively interested in reforming of education in Ukraine.

In our opinion, such educational innovations as freedom to choose or create the program, decentralization in management of educational establishments, distance studying during courses of qualification improvement, various forms of qualification improvement (webinars, seminars, workshops) and institutions that provide it and system of independent teachers' certification have impact on building pedagogical mastership of physical education teachers. That is why we have investigated level of support for these educational innovations among physical education teachers (Moskalenko, Bodnar, Sorokolit, Rymar, \& Solovey, 2020).

The highest level of support has such educational innovation as freedom to choose or create studying program. Such innovation is supported by $77,4 \%$ or questioned teachers. Teachers think that this innovation has essential role in building professional mastership as it allows to make author programs, based on 
their own pedagogical experience. It worth to mention that difference in respondents' answer is statistically not significant $(p=0,66)$. Such a high level of support we can explain by the fact that majority of respondents are specialists with higher $(44,8 \%)$ and first $(26,3 \%)$ qualification category. The teachers from these categories already had the opportunity to work with different studying programs in physical education subject. With this, the highest level of support is noticed among respondents from Lviv region $-82,0 \%$, Kmelnytsk region $79,2 \%$, Ternopil and Dnipropetrovsk regions - 77,8\% each. These results represent high level of support. The lowest percentage of support we have got from physical education teachers from Kherson and Vinnytsia regions $-74,0 \%$ each, what belong to higher than average results group (Fig. 1).

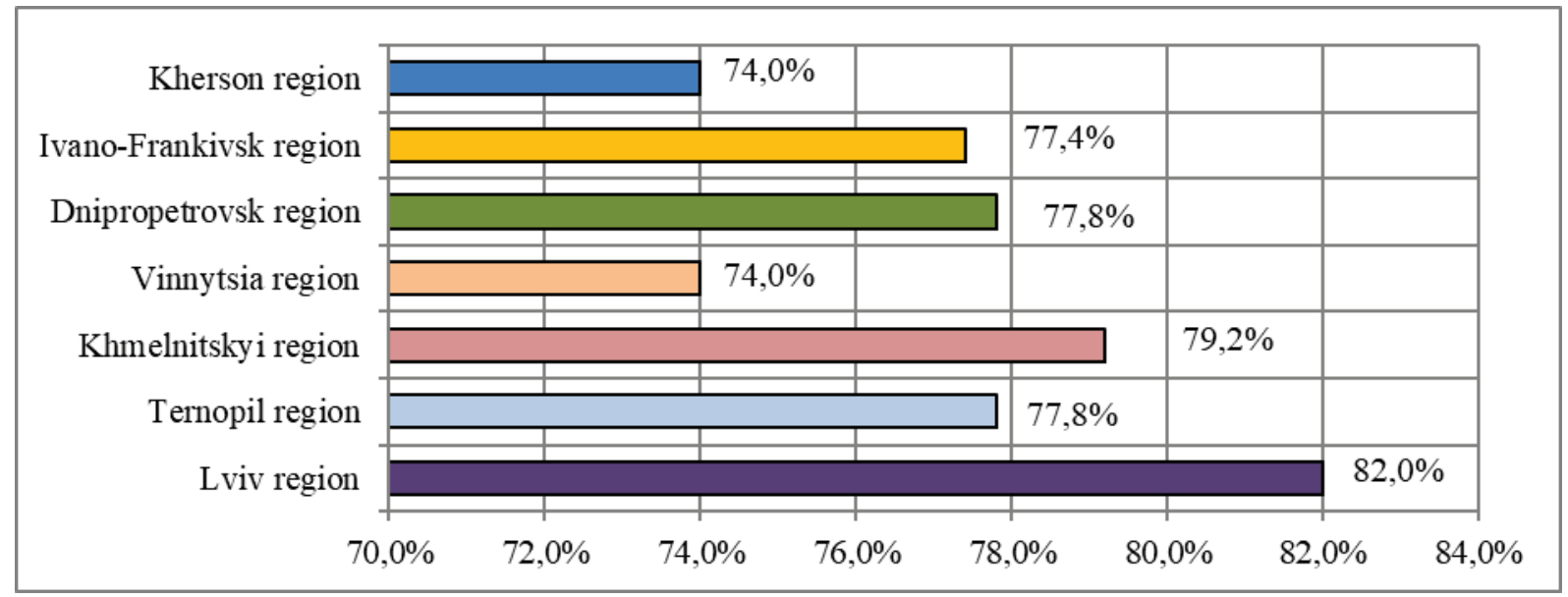

Figure 1 Percentage Value of the Support Level of Freedom to Choose or Create Studying Program by Physical Education Teachers in Different Regions of Ukraine

Despite the high level of support of this educational innovation, $41,9 \%$ of respondents think that the most effective way is to teach the subject "Physical education" according to the only studying program, that is proved by the profile ministry. Such opinion have $49,1 \%$ of respondents in Ivano-Frankivsk region, $41,7 \%$ in Dnipropetrovsk region, $48 \%$ in Vinnytsia region, $45,8 \%$ in Khmelnytskyi region, 40,0\% in Kherson region, 38,9\% in Ternopil region and $30,0 \%$ in Lviv region. The significant difference between respondents was not discovered $(\mathrm{p}=0,47)$.

But in Lviv region (44,0\%) and Ternopil region (42,6\%) teachers are convinced that the most effective way to teach a subject is adapting the only studying program according the conditions of educational establishments. According to teachers' thoughts it helps to show creativity and own pedagogical experience in planning studying documentation, according to state standard, that 
Sorokolit et al., 2021. New Ukarinian School Educational Reforms and Proffessional Mastership of the Physical Education Teacher

will positively influence pedagogical improvement and quality of physical education lessons.

The low level of support (6,5\% of physical education teachers) has opportunity to work according to author programs. The most prepared for creating author studying programs are physical education teachers from Kherson region $(12,0 \%)$ and Vinnytsia region $(12,0 \%)$. The lowest percentage are in respondents from Khmelnytskyi region (2,1\%), Ternopil region $(1,9 \%)$ and Ivano-Frankivsk region $(1,9 \%)$. There is no significant difference in respondents' answers $(\mathrm{p}=0,46)$.

The second place has got innovation - providing different forms of qualification improvement (webinars, seminars, workshops) of pedagogical workers and institutions that provide it. This educational innovation is supported by $74,4 \%$ of physical education teachers. Worth mentioning that this innovation is not supported evenly, there is statistically significant difference in answers of respondents $(\mathrm{p}=0,00)$. The high level of support is noticed in Dnipropetrovsk region $(88,9 \%)$, Ivano-Frankivsk region $(88,7 \%)$, Khmelnytskyi region $(85,4 \%)$ and Ternopil region (77,8\%). With this, teachers emphasize that only combination of theoretical studying according to educational program and performing of practical lessons in form of open lessons or workshops might effectively influence on forming professional mastership. Higher than average level of support is found out among respondents from Vinnytsia region $(74,0 \%)$.

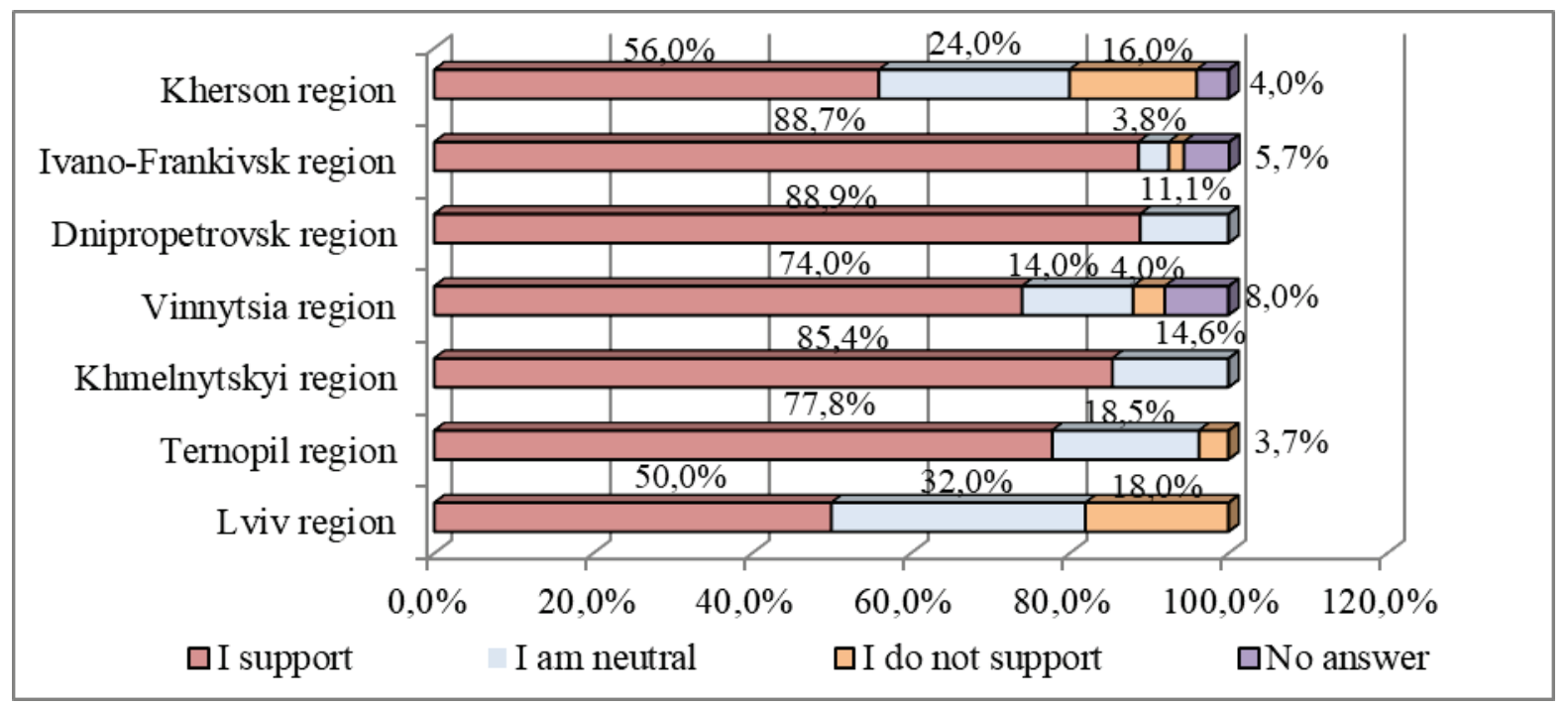

Figure 2 Percentage Value of Physical Education Teachers' Attitude towards Implementing Different Forms of Qualification Improvement 
The support for different forms of qualification improvement noticed in half of respondents from Kherson (56,0\%) and Lviv region (50,0\%) (Fig. 2).

Higher than average level of support also has such educational innovation as system of distance studying of qualification improvement of teachers. This educational innovation support $59,7 \%$ of respondents. High level of support exist among physical education teachers from Ternopil region (79,6\%). In Dnipropetrovsk region it is lower than average as only 33,3\% of respondents threat this innovation as effective for improvement of pedagogical mastership. This indicator is higher than average in other respondents and fluctuates from $56,0 \%$ in Vinnytsia region to $66,0 \%$ in Lviv region (Fig. 3).

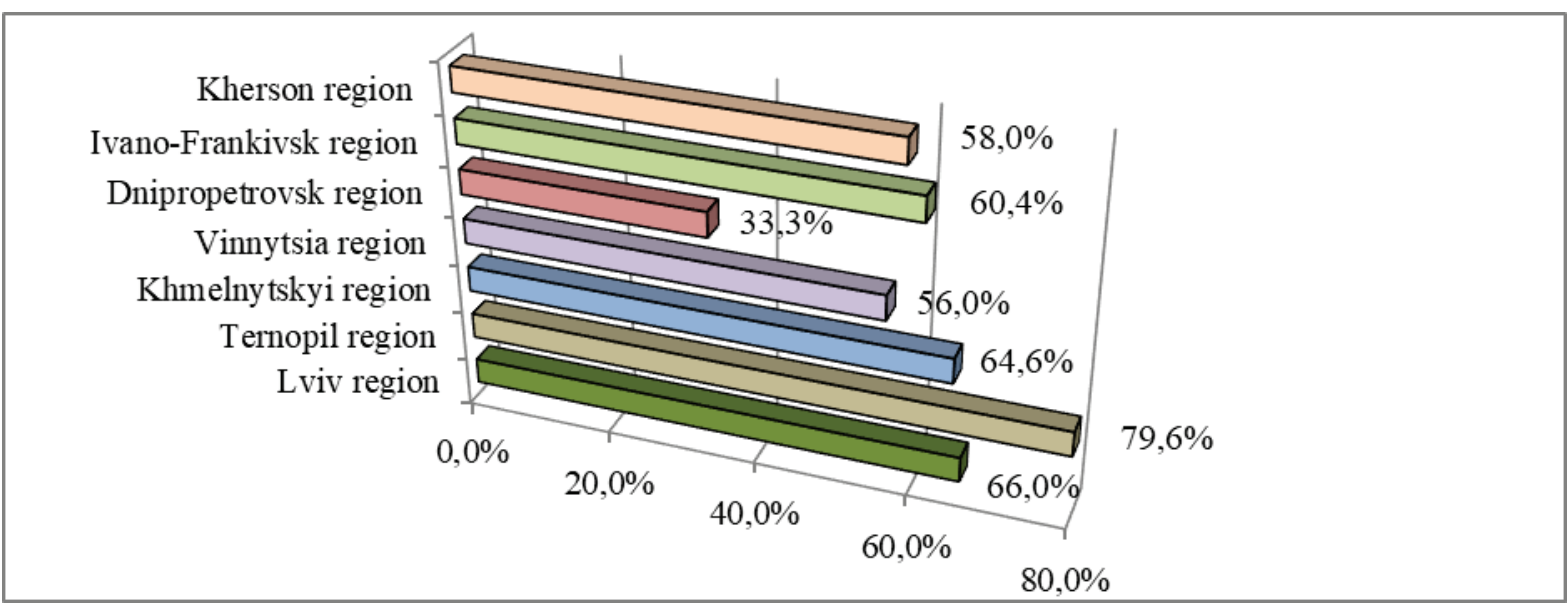

Figure 3 Percentage Value of Support to the System of Distance Studying of Qualification Improvement of Teachers

The implementation and providing of independent certification is supported by 53,6 participants of the survey. Such innovation has revealed statistically significant difference in the respondents' answers $(\mathrm{p}=0,02)$. The highest percentage of support is among physical education teachers from Lviv region $70,0 \%$ and the lowest level is from Khmelnytskyi region - 39,6\%. In Kherson region the certification is supported by $60,0 \%$ of physical education teachers, in Dnipropetrovsk region $-58,3 \%$, in Ternopil region - 53,7\%, in Vinnytsia region $-52,0 \%$, in Ivano-Frankivsk - 41,5\%.

Decentralization of educational establishments as an effective form of management of educational establishment is supported by $39,1 \%$ of physical education teachers. This result belongs to group "lower than average" level of support. Respondents' answers differentiate statistically $(\mathrm{p}=0,002)$. The highest percentage of support of this educational innovation is found in Lviv region $48,0 \%$, Vinnytsia region $-42,2 \%$ and Kherson region $-42,0 \%$. A little higher 
Sorokolit et al., 2021. New Ukarinian School Educational Reforms and Proffessional Mastership of the Physical Education Teacher

indicator from average, revealed in Ivano-Frankivsk region - 39,6\%. The lowest percentage of support to school decentralization is found in Dnipropetrovsk region $-33,3 \%$.

\section{Discussion}

The performed research showed that not all the reforms from New Ukrainian School that are directed to form professional mastership and are realizing in education have equal level of support among physical education teachers. The interesting fact is that such educational innovation as providing different forms of qualification improvement of pedagogical workers (webinars, seminars, workshops) and institutions that provide this did not get consistent opinion among physical education teachers. We assume that low level of support of this innovation in Lviv and Kherson region can be connected with high level of conservatism among physical education teachers and quality of courses for qualification improvement in these regions and also with high percentage of teachers with working experience more than 30 years.

Teachers from Vinnytsia region $(56,0 \%)$ and Lviv region $(66,0 \%)$ do not think it might be effective to increase own pedagogical mastership. It can confirm our assuming about physical education teachers' conservatism towards innovations, their high level of trust towards regional institution of postgraduate pedagogical education, the desire of classroom communication and knowledge sharing and also lack of information technology skills among physical education teachers from those regions.

In our opinion, the result according teachers' certification is a little bit strange. The average indicator in regions, we have questioned is 53,6\%. Especially low this indicator is in Khmelnytskyi $(39,6 \%)$ and Ivano-Frankivsk $(41,5 \%)$ regions. This result did not confirm our assuming. We were thinking that certification may become good motivation for self-education and selfimprovement of professional competences, as well as successful passing the certification will bring $20 \%$ increase in teachers' salaries for three years for those who passed. Among reasons for such attitude may be: teachers' conservatism, low confidence in its own pedagogical mastership, intolerance to changes, lack of desire to extra preparation to theoretical and practical components of certification, fear not to confirm their existing qualification category according to results from previous attestation.

Our research showed that physical education teachers are not ready to create author programs nowadays, majority of teachers support implementing in their practice the only studying program that is proved by profile ministry. Only 
$6,5 \%$ of teachers think that their pedagogical experience and mastership allow to create author programs and perform their professional responsibilities according to these programs. In our opinion, among the reasons that make it impossible to create author programs might be lack of confidence in own pedagogical experience, lack of desire to show creativity, fear of criticism from colleagues according their work and absence of knowledge in how to conclude a program.

\section{Conclusions}

Thus, our research has showed that innovations, proposed by educational reform "New Ukrainian School", to form pedagogical mastership in general have higher than average and lower than average levels of support. High level of support has only such innovation as freedom to choose or create studying program $-77,4 \%$. However, $41,9 \%$ of teachers think that they should teach pupils according to the only studying program, confirmed by profile ministry. Only $6,5 \%$ of respondents are ready to conclude author educational programs; $33,8 \%$ of respondents think that educational program from physical culture should be adapted according to educational establishments' conditions. The results of the research testify that to form professional mastership such innovations as different forms of qualification improvement $(71,3 \%)$, distance studying during course retraining $(59,7 \%)$, teachers' certification $(53,6 \%)$ become important part. The lowest level of support has the innovation of management decentralization in educational establishments $(39,1 \%)$.

\section{Acknowledgment}

The author of the article expresses sincere gratitude to administration of regional institutions of postgraduate education in Lviv, Ternopil, IvanoFrankivsk, Khmelnytskyi, Vinnytsia, Dnipropetrovsk and Kherson regions for assistance in performing teachers' questionnaire.

\section{References}

Arefieva, L.P. (2010). Pidhotovka maibutnikh uchyteliv fizychnoi kultury do pozaklasnoi vykhovnoi roboty $v$ starshii shkoli. Kandydatska dysertatsiia. Natsionalnyi pedahohichnyi universytet im. M.P.Drahomanova, Kyiv.

Avalos, B. (2011). Teacher professional development in teaching and teacher education over ten years. Teaching and Teacher Education, 27(1), 10-20. DOI: https://doi.org/10.1016/j.tate.2010.08.007 
Sorokolit et al., 2021. New Ukarinian School Educational Reforms and Proffessional Mastership of the Physical Education Teacher

Azhyppo, O. Yu. (2013). Teoretyko-metodychni zasady pidhotovky maibutnikh uchyteliv fizychnoi kultury do profesiinoi diialnosti u zahalnoosvitnikh navchalnykh zakladakh. Doktorska dysertatsiia. Kharkivskyi natsionalnyi pedahohichnyi universytet im. H.S.Skovorody, Kharkiv.

Deminska, L. O. (2014). Aksiolohichni zasady profesiino-pedahohichnoi pidhotovky maibutnikh uchyteliv fizychnoho vykhovannia. Doktorska dysertatsiia. Kyivskyi universytet im. Borysa Hrinchenka, Kyiv.

Dezimone, L.M. (2009). Improving Impact Studies of Teachers' Professional Development: Toward Better Conceptualizations and Measures. Education Researcher, 38(3), 181199. DOI: https://doi.org/10.3102/0013189X08331140

Fedorchuk, E., Konkova, T., Fedorchuk, V., \& Zaremba V. (2006). Osnovy pedahohichnoi maisternosti. Kamianets-Podilskyi: Vydavets Zvoleiko D.

Konukman, F. (2015). Reform in Physical Education Teacher Education (PETE): A Critical Inquiry for the Future. International journal of Science Culture and Sport, 3(4), 6-21. DOI: https://doi.org/10.14486/IntJSCS449

Kougioumtzis, K., Patriksson, G., \& Strahlman, O. (2011). Physical education teachers' professionalization: A review of occupational power and professional control. European Physical Education Review, 17(1), 111-129. DOI: https://doi.org/10.1177/1356336X11402266

Kurnyshev, Yu.A. Pedahohichni umovy profesiinoho samorozvytku maibutnikh uchyteliv fizychnoi kultury. Kandydatska dysertatsiia. Natsionalnoi akademii pedahohichnykh nauk Ukrainy, Kyiv.

Little, J.W. (1993). Teachers' professional development in a climate of educational reform, systemic reform: Perspectives on personalizing education. Educational Evaluation and Policy Analysis, 15(2), 129-151.

Matviichuk, T.F. (2015a). Osoblyvosti formuvannia pedahohichnoi maisternosti vchyteliv fizychnoi kultury. Naukovyi chasopys NPU im. M. P. Drahomanova. Seriia 15: Naukovo-pedahohichni problemy fizychnoi kultury: (fizychna kultura i sport), 5 (K) 61, 163-167.

Matviichuk, T. F. (2015b). Formuvannia pedahohichnoi maisternosti maibutnikh uchyteliv fizychnoho vykhovannia u protsesi profesiinoi pidhotovky. Kandydatska dysertatsiia. Lvivskyi naukovo-praktychnyi tsentr instytutu profesiino-tekhnichnoi osvity, Lviv.

Moiseiev, S.O. (2017). Suchasni trendy v semantychnomu prostori konstruktu «pedahohichna maisternist». Pedahohichnyi almanakh, 35, 165-172.

Moiseiev, S.O. (2018). Rozvytok pedahohichnoi maisternosti vchytelia fizychnoi kultury u vymirakh fakhovykh konkursiv. Kherson: Akademiia neperervnoi osvity.

Moskalenko, N., Bodnar, I., Sorokolit, N., Rymar, O. \& Solovey, A. (2020). Analysis of Attitudes to educational reforms in Ukraine of Physical Education teachers and primary education teachers. Society. Integration. Education: proceedings of the International Scientific Conference. May 22th-23th, 2, 119-129.

DOI: http://dx.doi.org/10.17770/sie2020vol2.4846

Omelchuk, O. V. (2014). Formuvannia profesiinoi kompetentnosti maibutnikh uchyteliv fizychnoi kultury u protsesi vyvchennia pryrodnycho-naukovykh dystsyplin. Kandydatska dysertatsiia. Natsionalna akademiia nauk Ukrainy, Instytut literatury im. T. H. Shevchenka, Kyiv. 
Papucha, V. M. (2010). Formuvannia pedahohichnoi maisternosti maibutnoho vchytelia fizychnoho vykhovannia $v$ protsesi fakhovoi pidhotovky. Kandydatska dysertatsiia. Klasychnyi pryvatnyi universytet, Zaporizhzhia.

Penkovets, D.V. (2013). Etapy formuvannia profesiinoi maisternosti u maibutnikh uchyteliv fizychnoi kultury. Visnyk Chernihivskoho natsionalnoho pedahohichnoho universytetu: Pedahohichni nauky, 110, 261-263.

Radkevych, V. O. (2012). Profesiina kompetentnist - skladova profesiinoi kultury. Pedahohichna i psykholohichna nauky v Ukraini: Profesiina osvita i osvita doroslykh. Kyiv: Ped. dumka, 63-74.

Savchenko, V.A. (2011). Formuvannia profesiinoi maisternosti vchyteliv fizychnoi kultury v systemi pisliadyplomnoi pedahohichnoi osvity. Naukovyi chasopys NPU im. M. P. Drahomanova. Seriia 16: Tvorcha osobystist uchytelia: problemy teorii $i$ praktyky, 14, 317-321.

Sorokolit N., Rymar O. \& Bodnarchuk O. (2020). Porivnialnyi analiz stavlennia uchyteliv fizychnoi kultury do osvitnikh reform v zakladakh zahalnoi serednoi osvity. Fizychne vykhovannia, sport ta ozdorovcha kultura v suchasnomu suspilstvi, 2(50), 20-25. DOI :https://doi.org/10.29038/2220-7481-2020-20-25

Sorokolit, N. (2018). Stavlennia uchyteliv fizychnoi kultury do osvitnikh novovveden reformy "Nova ukrainska shkola". Sportyvna nauka Ukrainy, 6(88), 53-59. Retrieved from http://sportscience.ldufk.edu.ua/index.php/snu/article/view/852/821

Sorokolit, N., Shyyan. O., Lukjanchenko, M., \& Turchyk, I. (2017). Improverment of 5-9th Grades Schoolchildren Physical Education in Ukraine by Using Variable Modules Curriculum. Journal of physical education and sport, 17 (4), 2110-2115. DOI: https://doi.org/10.7752/jpes.2017.s4215

Stepanchenko, N.I. (2017). Systema profesiinoi pidhotovky maibutnikh uchyteliv fizychnoho vykhovannia $u$ vyshchykh navchalnykh zakladakh. Doktorska dysertatsiia. Vinnytskyi derzhavnyi pedahohichnyi universytet im. M. Kotsiubynskoho, Vinnytsia.

Tannehill, D., Demirhan, G., Chaplova, P., \& Avsar, Z. (2021). Continuing professional development for physical education teachers in Europe. European Physical Education Review, 27(1), 1150-1167. DOI: https://doi.org/10.1177/1356336X20931531

Veselovskyi, A., Redchyts, V. \& Ilchyshyn, I. (2016). Okremi napriamy profesiinoi pidhotovky fakhivtsia fizychnoi kultury u svitli vymoh sohodennia. Aktualni pytannia humanitarnykh nauk, 15, 277-283.

Vindjuk, A. V. (2013). Profesiina pidhotovka maibutnikh uchyteliv fizychnoi kultury do formuvannia $\mathrm{v}$ uchniv uminnia samostiino vykonuvaty fizychni vpravy. Zbirnyk naukovykh prats Berdianskoho derzhavnoho pedahohichnoho instytutu, 2, 20-26.

Yurieva, L., Sava, M., \& Yavorskyi, Yu. (2009). Osoblyvosti profesiinoi maisternosti maibutnoho fakhivtsia fizychnoi kultury. Fizychne vykhovannia, sport $i$ kultura zdorovia u suchasnomu suspilstvi, 3, 38-41. 